\begin{tabular}{c}
\hline Jurnal Kesehatan Masyarakat \\
http://journal.unnes.ac.id/nju/index.php/kemas
\end{tabular}

\title{
Gadget as Risk Factor to Speech and Language Delay in Autism Children
}

\author{
Muhammad Kamal ${ }^{\bowtie}$, Nurul Syahriani Salahuddin, Misdayanti
}

Public Health Department Faculty of Health Sciences, Avicenna Institute of Technology and Health, Indonesia

\section{Article Info}

Article History:

Submitted November 2019

Accepted January 2020

Published July 2020

\section{Keywords:}

Gadgets, Speech and

Language Delay, Autism

DOI

https://doi.org/10.15294/

kemas.v16i1.21875

\begin{abstract}
Users gadgets not only among adults but the age of adolescence and early age as a kindergartner and a toddler was already using the gadget. The child's brain at the age of $0-5$ years is in the golden development period (golden age). Toddler is the most important period in optimally increasing children's development because it can influ-ence and determine children's development going forward. The use of gadgets from an early age will have an im-pact on children's development that can trigger the incidence of autism. The purposed of this studied was to de-termine the effect of using gadgets on developmental delays in speech and language aspects in children with au-tism. This type of research is an observational analytic studied used a cross sectional approach. Respondents numbered 33 people. This research was conducted at the Autonomous Service UPTD of Southeast Sulawesi Edu-cation Office. Bivariate analysis showed that the intensity of the use of gadgets was related to the development of speech and language ( $\mathrm{p}$ value $=0.011$; $\mathrm{OR}=16,000)$. In this case, parental supervision is very important in providing limits and controlling the playing time of the gadget to optimize the growth and development of children.
\end{abstract}

\section{Introduction}

Technological developments occur very rapidly in the field of information and communication technology. In the current era of globalization, a person's media to conduct social interactions, especially to make social contacts and communicate only using gadgets. At this time, gadget users are not only among adults, but teenagers and young people such as kindergardens and toddlers are already using gadgets (Rozalia, 2017). Based on data from KOMINFO (2013-2018) the number of internet users reached 3.6 billion people. Indonesia is ranks $6^{\text {th }}$ as an active country in accessing the internet after China, the United States, India, Brazil and Japan. Most of the gadgets for children aged under five years in Indonesia reaches $27 \%$, in the year 2014 increased to $73 \%$. $29 \%$ of them already have a personal gadget given by parents.

The introduction of children to gadgets usually starts from the wrong way of transferring from parents or family by showing games or videos in the gadget so that children do not fuss or stop crying and parents are more free to do activities without having to accompany children to play (Pebriana, 2017).Toddler is the most important period in optimizing child development because it can influence and determine children's development going forward (Gunawan et al., 2016). At this time the use of gadgets is one of the parents' shortcuts in the companion as a caregiver for their children. With a variety of interesting features and applications, children more often use gadgets to play games than to study or play outside the home with their friends. The use of gadgets in infants will have an impact on children's 
development. In one study by Novitasari (2016) in (Pebriana, 2017), said that the use of gadgets in early childhood is more fun than playing with peers. Children who play gadgets tend to be silent in front of their respective gadgets regardless of the world around them. Unconsciously, children have experienced the dependence of using gadgets and this is one of the impacts that is very influential on children's development.

The results of another study are conducted by (Fajariyah et al., 2018), in Surabaya who said that the use of gadgets has a great influence on the development of speech and language. Gadgets addiction causes children to be lazy to move and not sensitive to the environment so that it can affect the child's development. The use of gadgets can make the family's role replaced by gadgets so that individuals prefer to be alone and do not make social contact, while psychosocial impaired children can cause children to stutter and talk too late. Every year around the world, cases of autism have increased. In 1990 cases of autism ranged from 1: 2,000 births. In the United States in 2000 this figure increased to 1 in 150 children who have a tendency to suffer from autism. Whereas in the United Kingdom, the latest data from the United States Center for Disease Control and Prevention in 2002 showed that the prevalence of autism is growing, at least 60 sufferers in 10,000 births and occurs in 6,000-15,000 children under the age of 15 years (Wardani, 2009). In 2013 the Director of Mental Health Development at the Ministry of Health had estimated the number of autistic children in Indonesia around 112,000 with a span of 5-19 years. This figure comes out based on a count of autism prevalence of 1.68 per 1000 children under 15 years. If the number of children aged 5-19 years in Indonesia reaches $66,000,805$ people based on BPS data in 2010, it is estimated that there are more than 112,000 autistic children aged 5-19 years in Indonesia (Wahyu, 2017).

Autism is usually detected before the age of 3 years. But there are also symptoms since the age of the baby with a delay in social interaction and language (progression) or have reached normal but before the age of 3 years the development stops and retreats, and there are signs of autism. Age of Kids of early (childhood) has a critical time period/golden period which is a period of growth and development of the most rapid in the human brain. At this time the brain is plastic compared to adults so that toddlers are very open and sensitive in accepting various kinds of learning and enrichment both positive and negative. Toddler growth and development will be optimal if the environment provides positive support or conversely. Over time, it has become commonplace that children already have gadgets in the form of smartphones, tablets, cellphones, laptops. Children who are in the golden period are experiencing inculcation of character, character and morals, should get serious attention.

Kendari city is the top area for autism sufferers in Southeast Sulawesi, as many as 120 people are undergoing therapy at the autism care center (UPTD-Education and Culture Office, 2018). According to Violence \& Gore (Dewanti et al., 2016), states that antisocial behavior is a negative impact of gadgets caused by gadget abuse. This happens when someone feels that the gadget is the single most important thing in his life, so the child does not care about the circumstances around him, which results in the child becoming less interacting with people around him and will have difficulty socializing and establishing relationships with people around him. The purposed of this studied was to determine the effect of using gadgets on developmental delays in speech and language aspects in children with autism at UPTD Autism Services Dikbud Southeast Sulawesi.

\section{Method}

This research is an analytic observational studied used cross sectional approach. The studied was conducted at the Autonomous Service UPTD of Southeast Sulawesi. The sample in this studied were mothers who have autism children who were treated in UPTD autism services as many as 33 people. This research was conducted in April to June 2019. The sampling technique in this study was simple random sampling. Data collection in this study was obtained directly from respondents through interviews using a questionnaire guide/questionnaire list, and filling in the pre-screening developmental questionnaire (KPSP). Statistical analysis uses bivariate 
analysis to analyze the significant effect between independent and dependent variables using the Chi Square test. Also note the odds ratio (OR). In addition, this study looked at respondent characteristics such as mother's education, mother's occupation, age of the child, gender, age of the child introduced / used gadget, type of gadget used. Mother's education is categorized into 3 groups namely higher education, secondary education, and basic education. Occupational mothers are categorized into groups that work and do not work. The age of the child is grouped into five (5) groups. The age grouping of children by age at KPSP is $24-36$ months, 37-48 months, 49 60 months, $61-72$ months, and $>73$ months. The sex of the respondents was divided into 2 groups, namely male and female. The age of the child to introduce / use the gadget is starting from the age of $<1$ year, 1 year, 2 years, 3 years. 4 years, up to $\geq 5$ years. While categorizing the types of gadgets that are commonly used are smartphones, tablets, and laptops. Children's speech and language development variables are measured using the KPSP form which contains 3 questions for children aged 24 months, 36 months, 54 months, and 60 months. While the number of questions on the KPSP form for 30 -month-old children is 4 questions.

\section{Result and Discussion}

Based on table 1 shows that the majority of parents of highly educated children amounted to 22 respondents (66.7\%). In the characteristics of work there is no significant

Table 1. Frequency Distribution of Respondent Characteristics

\begin{tabular}{llll}
\hline Characteristics of Respondents & Category & Frequency & $\%$ \\
\hline Mother/Level of education & High & 22 & 66.7 \\
& Intermediate & 10 & 30.3 \\
& Basic & 1 & 3.0 \\
Occupation of Mother & Does not work & 17 & 51.5 \\
& Work & 16 & 48.5 \\
Age of Child (Month) & $24-36$ & 5 & 15.2 \\
& $37-48$ & 12 & 36.4 \\
& $49-60$ & 5 & 15.2 \\
& $61-72$ & 2 & 6.1 \\
Gender of Children & $>73$ & 9 & 27.3 \\
& Male & 29 & 87.9 \\
\hline
\end{tabular}

Source: Primary data, 2019

Table 2. Distribution of Respondents Answers on the Use of Gadgets

\begin{tabular}{llll}
\hline Item Questions About & Parameter & Frequency & Percentage \\
Using Gadgets & & 4 & $12.12 \%$ \\
\hline The age of the child is introduced & $<$ year & 4 & $12.12 \%$ \\
/ using the gadget & 1 year & 18 & $54.54 \%$ \\
& 2 years & 2 & $6.06 \%$ \\
& 3 years & 2 & $6.06 \%$ \\
\multirow{2}{*}{$\begin{array}{l}\text { Types of gadgets commonly used } \\
\text { by children }\end{array}$} & 4 years & 3 & $9.09 \%$ \\
& Smartphone & 25 & $75.75 \%$ \\
& Tablet & 4 & $12.12 \%$ \\
& Laptop & 4 & $12.12 \%$ \\
\hline \multirow{5}{*}{$\begin{array}{l}\text { The response given by children } \\
\text { when using gadgets }\end{array}$} & Do not turn when called & \\
& Do not care about the environment \\
& Likes to be alone & \\
& Not answering when spoken to & \\
& Angry when you are disturbed or the gadget is taken
\end{tabular}

Source: Primary data, 2019 
difference between working mothers and nonworking mothers. There were 17 respondents who were unemployed (51.5\%). While working mothers were 16 respondents (48.5\%). Parents who work include civil servants and entrepreneurs. Patients undergoing therapy in UPTD Autism-Education and Culture Office of Sultra are children whom are in the age range of 37-48 months (3-4 years) as many as 12 children (36.4\%), aged $>73$ months ( $\geq 6$ years) as many as 9 children (27.3\%). Whereas most of the therapeutic patients were male, amounting to 29 children (7.9\%).

Table 2 shows that the majority of children were introduced / used gadgets at the age of 2 years ( 24 months) as many as 18 children (54.54\%). While the types of gadgets which are comonly used by children are smartphones as many as 25 children (75.75\%), when using gadgets, the majority of responses given by children are not turned away when called, do not care about the environment, like to drive, do not answer when invited to talk, angry when disturbed or the gadget is taken, and rarely play with friends.

Based on the results of the study, the intensity of the use of children's gadgets seen based on the age of the child being given a gadget can be seen in table 3 .

Table 3 shows that the intensity of the use of gadgets majority is high category, by $78.8 \%$. This is illustrated by the number of respondents who said that children can spend time in front of the gadget that is about one hour or more per day, there are even respondents who say that children use gadgets for hours and fall asleep. The average child uses a gadget every day per week and at least 30 minutes per day. While the intensity of the use of gadgets lower categories by $21.2 \%$. For children with low-intensity gadget usage, parents limit the duration of gadget usage to a minimum of 15 minutes and 1-4 times per week.

The results of the bivariate statistical analysis showed that the variable of speech and language development had a $\mathrm{p}$ value of 0.011 ( $\mathrm{p}$ $<0.05$ ), meaning that there was a relationship between the intensity of the use of gadgets on the of speech and language delay. Table 5 shows an odds ratio of 16 so that children with low intensity of gadget usage have a chance of 16 times to develop in normal aspects of speech and language compared to children who use gadgets with high intensity. This means that the lower the intensity of the use of gadgets, the lower the opportunity to experience developmental delay in aspects of speech and language.

Development is a pattern of change that starts from conception, which continues along the life span which includes progressive addition to skills and abilities in various aspects, namely motoric (rough and smooth), language or communication (reception, expression, articulation), cognitive, and social adaptation Santrock in (Zulaekah et al., 2014). The

Table 3. Intensity of Gadget Usage

\begin{tabular}{lll}
\hline Intensity of Use of Gadgets & Frequency & Percentage \\
\hline Low & 7 & 21.2 \\
High & 26 & 78.8 \\
Amount & 33 & 100.0 \\
\hline
\end{tabular}

Source: Primary data, 2019

Table 4. Intensity of Use Gadgets on the Development of Speech and Language

\begin{tabular}{|c|c|c|c|c|c|c|c|c|}
\hline \multirow{3}{*}{ Intensity Use of Gadgets } & \multicolumn{4}{|c|}{$\begin{array}{c}\text { Speech \& Language } \\
\text { Delay }\end{array}$} & \multirow{2}{*}{\multicolumn{2}{|c|}{ Amount }} & \multirow[t]{2}{*}{ OR } & \multirow[t]{2}{*}{ P Value } \\
\hline & \multicolumn{2}{|c|}{ Well } & \multicolumn{2}{|c|}{ Less } & & & & \\
\hline & $\mathrm{n}$ & $\%$ & $\mathrm{n}$ & $\%$ & $\mathrm{n}$ & $\%$ & \multirow{4}{*}{16} & \multirow{4}{*}{0.011} \\
\hline Low & 4 & 12.1 & 3 & 9.1 & 7 & 21.2 & & \\
\hline High & 2 & 6.1 & 24 & 72.7 & 26 & 78.8 & & \\
\hline Amount & 6 & 18.2 & 27 & 81.8 & 33 & 100.0 & & \\
\hline
\end{tabular}

Source: Primary data, 2019 
aspect of children's growth and development is something that needs special attention in children, because it is an aspect that explains the process of forming someone both physically and psychosocially (Solikah \& Suminar, 2017). One aspect of development that needs to be monitored according to the Ministry of Health (2013), is the ability to speak and language that is related to the ability of children to respond to voices that are heard, speak, communicate, follow orders given, and so on.

Autism can be classified based on grouping of conditions. Based on the results of most studies classified as autism fixation that is autism children whom at birth are in normal condition, signs of autism appear later after two or three years old. This is in accordance with the theory that says that the important period in child development is the toddler period. Age at 2 years is known as the toddler years past golden age once the critical period for the growth and development of the most rapid in the human brain. Normal language development in toddlers involves the left hemisphere in the brain. The left hemisphere is the center of language skills and starts functioning in the womb, but functions perfectly after a few years later. At this time the brain is plastic compared to adults so that toddlers are very open and sensitive in accepting various kinds of learning and enrichment both positive and negative so that necessary stimulation/stimulation is useful for potential growth (Usman \& Sukandar, 2014). The process of growth and development of children is often regarded as a natural process and left alone without any special attention from parents. This is supported by the lack of knowledge, education, and attitudes of parents, especially mothers in supporting the growth and development of children, especially in terms of the quality of care (Tjandrajani et al., 2016).

Language development is one indicator of the overall development of children's cognitive abilities related to success in school. Delay in the development of early language skills can affect various functions in daily life and also affect social personal life (Hartanto et al., 2016). Child's growth and development is greatly influenced by stimuli provided by the surrounding environment. If the stimulus goes well, it can make the child have cognitive abilities, motor skills, and language that develops very well too. Conversely, if there is a developmental disruption during that period there will be a developmental disorder that is autism (Artanti, 2012). The exact cause of autism is unknown but autism can occur from a combination of various factors, including environmental factors. There are various theories that explain the factors that influence the occurrence of autism, one of which is psychosocial theory. Some experts consider that the incidence of autism is considered as a result of a cold/unfamiliar relationship between parent and child. When children use gadgets, children become difficult to communicate, do not care and do not respond when parents ask them to talk. In addition, children also do not make social contact and do not get stimulation because children are only focused on gadgets.

The prevalence of autism in children ranges from 2-5 sufferers out of 10,000 children is under the age of 12 years (Siyoto, 2015). The most vulnerable age is in infancy because at this time is the formation of a child's personality. Based on the results of the study it can be seen that the majority of children who suffer from autism are male. This is consistent with the theory that the prevalence of autism ranges from 1-2 per 1000 population with the distribution of men more than women with a ratio of 4: 1 . Autism is more dominant in male children because they have lower brain function endurance than female. In males the development of the right hemisphere is responsible for abstract tasks and requires skills (Dewanti et al., 2016).

The results showed that the majority of patients undergoing therapy in the Southeast Sulawesi Regional Autonomy UPTD were children in the age range of 37-48 months (3-4 years). Age 3-6 years is the age range of preschool children. At this time, children who initially only get informal education from parents/family, will begin to get to know the environment outside the home and will meet with their peers. So that at this stage children will play more often, are more active, have more curiosity. By playing it will provide stimulation that can stimulate the child's brain so that it can improve the growth and 
development of children such as the ability of movement, speech and language, socialization, and independence of children. If at this time children use gadgets in excess, it can interfere with the development of empathy, social, and problem solving skills because gadgets have replaced the role of limbs in the development of sensory and visual motor skills.

The results of this study are supported by research conducted by (Mulyantari et al., 2019), in Bandung who said that there is a relationship between the habit of using gadgets based on duration and mental emotional status. Where at preschool age physical activity develops and skills increase as well as thought processes. The way to learn at preschool age is to play. The use of gadgets with a long duration can limit the physical activity of children to play, so that children lack the stimulus to be able to develop motor and social skills. The American Academy and Pediatrics (AAP) does not recommend giving gadgets to children under 3 years of age because in this period children have a short concentration range so they are easily bored with excessive stimulation. Adequate and quality sleep actually has a big impact on the development of a child's brain. Stimulation and use of gadgets with excessive intensity can make children experience impaired concentration and damage the ability to control themselves.

The results showed that there was an influence on the intensity of the use of gadgets on children's speech and language development. Most patients undergoing therapy in UPTD Autism- Education and Culture Office of Sultra are children who are in the age range of 37-48 months (3-4 years). The age range is a critical period for the development of speaking and language skills. Children who are learning to speak, will observe closely the faces of the interlocutors and the movements, they do until there is an increase in understanding the verbal signals of hearing. The first $2-4$ years show a rapid increase in the number and complexity of speech development, vocabulary richness and neuro-motor control. Some of the factors that cause speech delay in children are not given stimulants from the closest people that greatly affect the child's development both motoric, cognitive, and personality development of children. In addition, it does not train children from an early age to communicate as an introduction (Puspita et al., 2019). The use of gadgets with high intensity has a negative impact, one of which is a decrease in psychomotor abilities which results in delayed speech development of children (Sukmawati, 2019). Children who get stimulus directed and regularly will develop faster than children who lack / do not get the stimulus. Children who use gadgets excessively make children only focus on their gadgets making it difficult to communicate, do not interact with peers, and do not get a stimulus that results in impaired speech and language development in children. Failure at this time in the pattern of parenting and education will affect the adult life.

The results showed an odds ratio of 16,000 so that children with low intensity of gadget usage had a 16,000 times chance to develop in speech and language aspects better than children who use gadgets with high intensity. Electromagnetic wave radiation from gadgets is not visible; the effect is not got directly. The danger of gadget radiation to children's developmental power is radiation from the use of gadgets that are classified as RF waves. RF waves are not deadly and dangerous waves, but that does not mean the possibility of side effects does not exist. RF radiation at high levels and intensive intensity can damage body tissue. The radiation can damage body tissues because the body is not equipped with a resistance system to anticipate excessive amounts of heat due to RF radiation. Nonionized radiation (including RF waves) has long-term effects. Diseases that have the potential to arise due to radiation gadgets are cancer, brain tumors, Alzheimer's, Parkinson's, headaches, developmental and behavioral disorders. Data shows that when the radiation from the gadget enters the adult's head absorbs as much as $25 \%, 12$-year-olds as much as $50 \%$, and the highest in 5 -year-olds is $75 \%$. The risk of this radiation will be greater in children who have long been exposed to gadgets from an early age (Chusna, 2017).

The results of this study are in line with research conducted by (Fajariyah et al., 2018), in Surabaya who said that the use of gadgets has a great influence on the development of speech and language. Gadgets addiction causes children to be lazy to move and not sensitive to 
the environment so that it can affect the level of aggression of children, behavior patterns, and psychosocial children. Interaction and communication with the environment is one way that can stimulate children's speech and language development. Communication can help children increase vocabulary. Stimulation through the visual senses and hearing causes the child's mental becomes unstable and lack of attention to other things. Children who are excessive in using gadgets will become addicted and rarely talk to people around them, so that children become less and even not get stimulation which can ultimately affect the development of speech and language. Barriers to later speech development not only affect children's social and personal adjustments, but can also affect children's academic adjustments.

Based on data from the International Congress on Autism in 2006 recorded 1 in 150 children have a tendency for autism. Autism symptoms in terms of communication disorders in the form of being late to talk or even not developing at all and often using strange language (Usman \& Sukandar, 2014). One of the negative effects of excessive use of gadgets is the disruption of brain development so that it inhibits the ability to speak and speak. Failure at this time in the pattern of care and education will affect the maturity. So parents, educators and the community must guide them to avoid negative influences (Febrino, 2017).

\section{Conclusion}

Excessive use of gadgets in children has a negative impact, one of which is that it can affect the growth and development of children, especially the development of speech and language. Preventive action that can be taken to minimize the influence of gadgets on children is that parents must play an active role in supervising and assisting children in using gadgets in terms of duration of use, frequency, and selection of game and educational applications. In addition, providing stimulation with various kinds of learning and enrichment that are positive is useful so that the children's potential can develop optimally.

\section{References}

Artanti, P.Y., 2012. A Descriptive Study of Therapy for Patients with Autism in Early Childhood at Mutia Center, Bojong District, Purbalingga
Regency. Indonesian Journal Of Early Childhood Education Studies, 1(1).

Chusna, P.A., 2017. The Influence of Media Gadgets on Child Character Development. Journal of Research Dynamics: Communication Media for Religious Social Research, 17(2), pp.315330.

Dewanti, A., Widjaja, J.A., Tjandrajani, A., \& Burhany, A.A., 2016. Characteristics of Speech Delays in the Development and Development Clinic of Khusus Tumbuh Kembang Rumah Sakit Anak dan Bunda Harapan Kita in 2008-2009. Sari Pediatri, 14(4), pp.230-234.

Dewanti, T.C., Widada, W., \& Triyono, T., 2016. The Relationship Between Social Skills and Use of Smartphone Gadgets on Student Achievement in State Senior High School 9 Malang. Journal of Guidance and Counseling Studies, 1(3), pp.126-131.

Fajariyah, S.N., Suryawan, A., \& Atika, A., 2018. Impacts of the Use of Devices for Child Development. Sari Pediatri, 20(2), pp.101105.

Febrino, F., 2017. Preventive Actions on the Negative Effects of Gadgets on Children. Noura: Journal of Gender and Child Studies, 1(1), pp.1-21.

Gunawan, G., Fadlyana, E., \& Rusmil, K., 2016. Relationship between Nutritional Status and Development of Children Aged 1-2 Years. Sari Pediatri, 13(2), pp.142-146.

Hartanto, F., Selina, H., Zuhriah, H., \& Fitra, S., 2016. The Influence of Language Development on Cognitive Development of Children aged 1-3 Years. Sari Pediatri, 12(6), pp.386-390.

Mulyantari, A.I., Romadhona, N., Nuripah, G., Susanti, Y., \& Respati, T., 2019. The Relationship between Gadget Usage Habits and Emotional Mental Status in Preschool Children. Journal of Health \& Science Integration, 1(1), pp.10-15.

Pebriana, P.H., 2017. Analysis of Gadget Usage on Social Interaction Ability in Early Childhood. Obsession Journal: Journal of Early Childhood Education, 1(1), pp.1-11.

Puspita, A.C., Perbawani, A.A., Adriyanti, N.D., \& Sumarlam, S., 2019. Analysis of Speech Delay in 5 Years Old Children. Lingua, 15(2), pp.154-160.

Rozalia, M.F., 2017. The Relationship Intensity of Using Gadgets and Learning Achievement of Class V Elementary School Students. JP2SD (Journal of Thought and Primary School Development), 5(2), pp.722-731.

Siyoto, S., 2015. Visual Schedule Towards the 
Decline of Behavioral Problems in Feeding Activities and Defecation in Children with Autism. Jurnal Ners, 10(2), pp.250-255.

Solikah, S.N., \& Suminar, S., 2017. The Effect of Swaddling on the Motoric Development of 3 Month Old Babies. Unnes Journal of Public Health, 6(3), pp.203-208.

Sukmawati, B., 2019. The Effect of Gadgets on the Speech Development of 3 Year Old in Kindergarten of Buah Hati Kita. SPEED Journal: Journal of Special Education, 3(1), pp.51-60.

Tjandrajani, A., Dewanti, A., Burhany, A.A., \& Widjaja, J.A., 2016. Main Complaint of Delays in General Development in the Clinic of Khusus Tumbuh Kembang RSAB Harapan
Kita. Sari Pediatri, 13(6), pp.373-377.

Usman, H., \& H. Sukandar., 2014. Growth and Development of Children Aged 3-24 Months in Conflict Areas. Kesmas: National Public Health Journal, 9(1), pp.44-49.

Wahyu, D.K., 2017. The Role of Parenting on SelfReliance Personal Hygiene for Autistic Children in Elementery School. Journal of Special Education, 9(2).

Wardani, D.S., 2009. Parents Coping Strategies Dealing with Autistic Children. Indigenous: Journal of Scientific Psychology, 11(1).

Zulaekah, S., Purwanto, S., \& Hidayanti, L., 2014. Anemia on Growth and Development of Children Malnutrition. KEMAS: Journal of Public Health, 9(2), pp.106-114. 